\title{
Social Components of the Obesity Epidemic
}

\author{
Josefina Bressan • Fernanda de Carvalho Vidigal • \\ Helen Hermana M. Hermsdorff
}

Published online: 21 December 2012

(C) Springer Science+Business Media New York 2012

\begin{abstract}
Obesity represents an important public health concern and has negative health and social consequences. Epidemiological and observational studies have contributed to highlighting the multifactorial and complex etiology of obesity. Among the social components of the obesity epidemic the following appear to be the most relevant: assortative mating, parental age, socio-economical status and educational level, body dissatisfaction, sleep conditions, sedentary environments by build neighborhood, energy saving devices, work occupation and alcohol consumption. The assortative mating and parental traits (age, education level) have shown an important influence on the weight of children. In turn, sleep deprivation may reduce the energy expenditure and increase food intake, which can explain a relation with obesity. Body dissatisfaction in childhood and adolescence seems to increase the risk of obesity in adulthood. The low physical activity and spent sedentary time can be associated with unfavorably built environment, including low walk ability, unsafe playgrounds and pedestrian pathways. Moreover, the obesity per se, over time, may reduce physical activity level and social ability as well as influence in assortative mating, and subsequent intergenerational obesity condition. All findings together demonstrated that social components of obesity are as complex as itself. In summary, more studies concerning social, cultural and environment traits are needed in order to assess the effect of excessive adiposity in its own occurrence and chronicity. In addition, it is urgent to include obesity prevention as a relevant topic on the public health agenda in developing countries.
\end{abstract}

J. Bressan $(\bowtie) \cdot$ F. de Carvalho Vidigal $\cdot$ H. H. M. Hermsdorff Department of Nutrition and Health, Federal University of Viçosa, Viçosa, Brazil

e-mail: jbrm@ufv.br
Keywords Assortative mating · Parental age · Body image · Sleep deprivation $\cdot$ Sedentary lifestyle $\cdot$ Alcohol consumption . Social components $\cdot$ Obesity $\cdot$ Obesity epidemic

\section{Introduction}

The occurrence of overweight/obesity, disorders-related complications with lost in the quality life has increased over time [1]. Often, the energy balance (energy intake and energy expenditure) has been considered as a main cause of obesity. However, obesity is a multifactorial disorder with gene-environment interaction, where existing treatments have yet failed $[2,3 \cdot \bullet, 4 \cdot \bullet]$.

The environment domain of obesity includes assortative mating, parental traits (e.g., age, education), body image, sleep condition, physical activity/sedentary lifestyle, alcohol consumption among several others (Fig. 1). All of them may act correlated and synergy to promote or prevent to excessive accumulation of body fat $[4 \cdot \bullet, 5 \bullet, 6 \bullet \bullet, 7,8 \bullet \bullet, 9]$. In contrast, obesity can lead to social inabilities, such as absenteeism, body dissatisfaction, depression, low self-esteem, lowincome, discrimination and stigmatizing attitudes [10-13].

Taken together, this review presents some aspects of social components of obesity in order to discuss the most current scientific literature about this relevant and unclear topic. Table 1 gives an overview on relevant findings, concerning the social components in development of obesity.

\section{Assortative Mating and Intergenerational Effect}

Assortative mating occurs when men and women do not mate at random with respect to phenotypic (e.g., height, age) and cultural traits (e.g., religious, education) [14]. In this case, the assortative mating also can occur according to 
Fig. 1 Relationships of social components in the obesity etiology

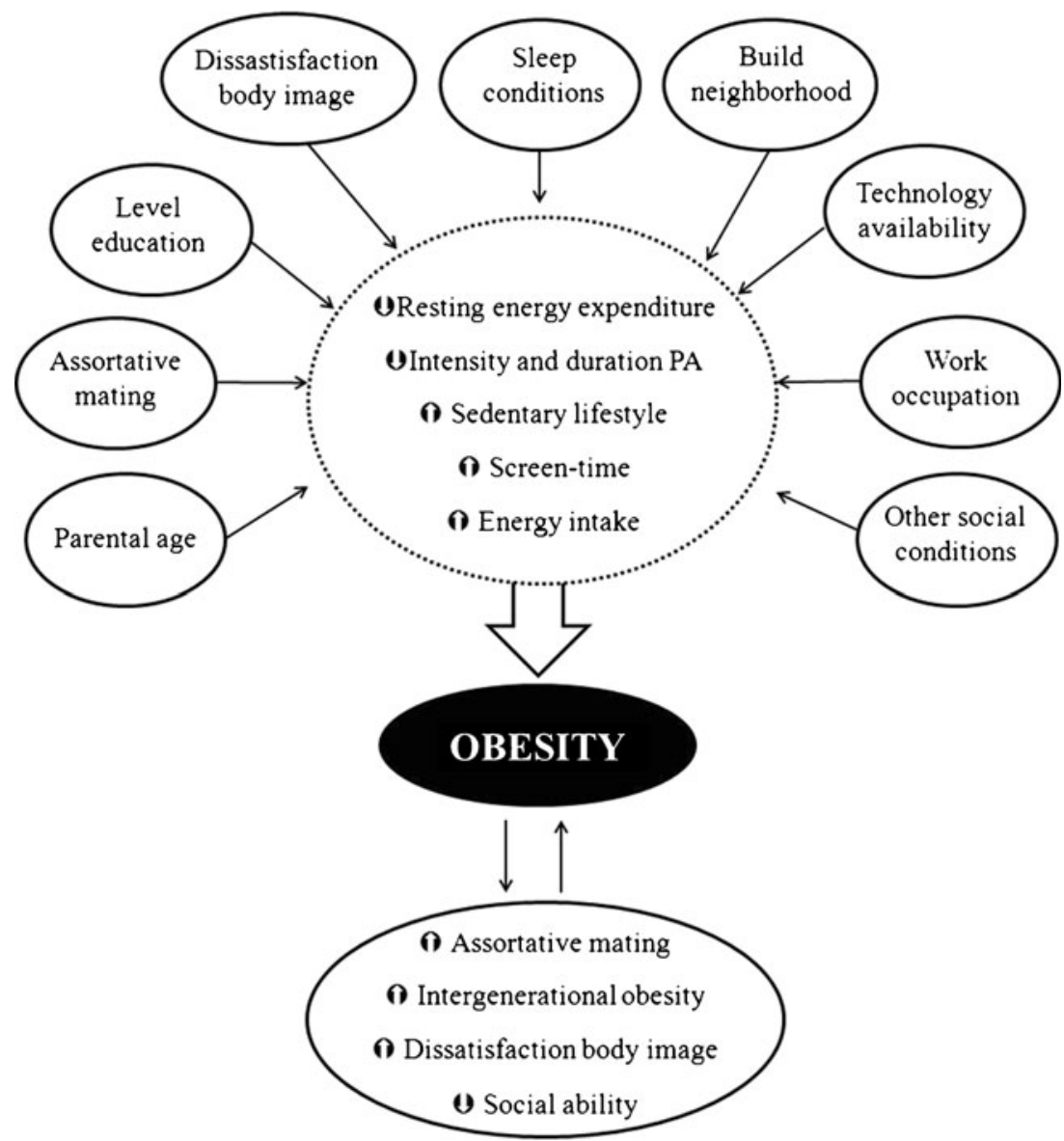

body weight or body fat, where human obesity would aggregate within families and increase its prevalence.

Recently, a total of 4,788 trios (father, mother, and child) from the general population-based Northern Finland Birth Cohort were investigated regarding the relationship between parental overweight history and weight gain in their children from pregnancy to 16 years old. Interestingly, when both parents' had long-term overweight $\left(\mathrm{BMI} \geq 25 \mathrm{~kg} \mathrm{~m}^{2}\right)$, before pregnancy and after 16-year follow-up, the children had higher risk of overweight, indicating an intergenerational transmission of obesity [15]. Other studies have also correlated pre-marital BMI, assortative marriage with the intergenerational effect on obesity $[16,17]$.

In the Longitudinal Study of Trios there were also big differences in BMI among the daughters grouped according to mothers' category of BMI and among the sons grouped according to their fathers' BMI, but not their daughters [5•]. In addition, the risks of obesity at 8-year follow-up were ten-fold and six-fold greater in girls and boys if the samesex parent was obese, regardless of birth weight of the child [5•]. In contrast, the metabolic z score (from HOMA-IR, triglycerides, and total cholesterol: HDL-c ratio) of the overweight/obese girls at 13 years was 14-fold greater than that of the normal-weight girls, but parental BMI had little influence on this outcome, suggesting own weight gain potentially increase the risk for metabolic disorders rather than that of their parents [18]. This hypothesis applies at least directly, since parental overweight had indirectly contributed to overweight occurrence.

If on one hand these findings confine the children to obese same-sex or both parents, considering obesity as a transmissible component, on the other hand the studies are not enough, and present some limitations, in view of the complexity in the obesity etiology. In this context, almost all previous studies used body mass index (BMI) as a measurement of obesity, the investigated relationships have not considered recognized assortative mating traits, such as age or social class [19, 20], and environment factors (physical activity, social and economic conditions, etc.) [4••, 21].

\section{Parental Age}

Population based cohort studies have provided growing evidence that advanced parental age at conception also might be associated with an increased risk of common and complex disorders [22]. Few studies have focused on the relationship regarding the paternal age at conception and the 
Table 1 Relevant findings, concerning the social components in development of obesity, obtained in the last three years

\begin{tabular}{|c|c|c|c|}
\hline Author [ref.] & Social components & Subjects/methods & Observations/main findings \\
\hline $\begin{array}{l}\text { Pérez-Pastor et al. } \\
{[5 \bullet]}\end{array}$ & $\begin{array}{l}\text { Assortative mating } \\
\text { and intergenerational effect }\end{array}$ & $\begin{array}{l}\text { Longitudinal study of trios; } n=226 \\
\text { child-mother-father trios from } \\
\text { Plymouth (UK); children followed } \\
\text { up for four annual time points } \\
\text { ( } 5 \text { to } 8 \text { years) }\end{array}$ & $\begin{array}{l}\text { The risk of obesity at } 8 \text { years was ten-fold } \\
\text { greater in girls and six-fold greater in } \\
\text { boys if the same-sex parent was obese }\end{array}$ \\
\hline $\begin{array}{l}\text { Jääskeläinen et al. } \\
\text { [15] }\end{array}$ & $\begin{array}{l}\text { Assortative mating and } \\
\text { intergenerational effect }\end{array}$ & $\begin{array}{l}\text { Northern Finland Birth Cohort; } \\
n=4,788 \text { child-mother-father trios; } \\
\text { children followed up from birth to } \\
16 \text { years-old }\end{array}$ & $\begin{array}{l}\text { Parental pre-pregnancy obesity } \\
\text { (mother or father) was strongly } \\
\text { predicted offspring overweight }\end{array}$ \\
\hline $\begin{array}{l}\text { Cuypers et al. } \\
{[8 \bullet \bullet]}\end{array}$ & Body dissatisfaction & $\begin{array}{l}\text { Hunt study; } n=1,196 \text { normal } \\
\text { weight adolescents }(13-19 \text { years }) \\
\text { followed up as young adults } \\
\text { (24-30 years) }\end{array}$ & $\begin{array}{l}\text { Adolescents who perceived themselves as } \\
\text { overweight had a mean difference in } \\
\text { overall weight gain (delta BMI) } \\
\text { that was } 0.88 \text { BMI units larger than } \\
\text { those who did not report } \\
\text { self-perceived overweight }\end{array}$ \\
\hline Mond et al. [32•] & Body dissatisfaction & $\begin{array}{l}\text { Prospective, epidemiological study; } \\
n=806 \text { girls }(n=440) \text { and boys } \\
(n=366), 11-13 \text { years, } \\
\text { followed up for } 5 \text { years }\end{array}$ & $\begin{array}{l}\text { Associations between obesity and } \\
\text { impairment in emotional well-being, } \\
\text { where these occur, are likely to be due } \\
\text { to the effects of weight-related body } \\
\text { dissatisfaction }\end{array}$ \\
\hline Cho et al. [36•] & Body dissatisfaction & $\begin{array}{l}\text { Cross-sectional study; } n=631 \text { students } \\
(349 \text { boys and } 282 \text { girls); } \\
\text { age }=\text { fifth and sixth grade students }\end{array}$ & $\begin{array}{l}\text { Body image distortion can lead } \\
\text { preadolescents } \\
\text { to develop stress about obesity and } \\
\text { unhealthy dieting practices, despite } \\
\text { similar obesity indices to those without } \\
\text { distorted body images }\end{array}$ \\
\hline Toor et al. $[40 \bullet]$ & $\begin{array}{l}\text { Sleep conditions and } \\
\text { circadian rhythm }\end{array}$ & $\begin{array}{l}\text { Case-control study; } n=45 \text { bariatric } \\
\text { surgical patients }(45.8 \pm 2.0 \text { years) } \\
\text { and } 45 \text { gender-matched non-obese } \\
\text { controls }(41.0 \pm 2.4 \text { years })\end{array}$ & $\begin{array}{l}\text { Individuals with extreme obesity, compared } \\
\text { to the non-obese, obtained less sleep and } \\
\text { experienced poorer sleep quality. Bariatric } \\
\text { surgery improved sleep duration and quality }\end{array}$ \\
\hline $\begin{array}{l}\text { Benedict et al. } \\
{[41 \bullet \bullet]}\end{array}$ & $\begin{array}{l}\text { Sleep conditions and } \\
\text { circadian rhythm }\end{array}$ & $\begin{array}{l}\text { Randomized and balanced crossover } \\
\text { study; } n=14 \text { healthy male } \\
(22.6 \pm 0.8 \text { years })\end{array}$ & $\begin{array}{l}\text { One night of sleep deprivation acutely } \\
\text { reduced energy expenditure in healthy men }\end{array}$ \\
\hline Briton et al. [54] & Sedentary lifestyle & $\begin{array}{l}\text { Women's Health Study; } n=19,003 \\
\text { women followed up nearly } 12 \text { years }\end{array}$ & $\begin{array}{l}\text { 7,865 women became overweight or obese. } \\
\text { The highest categories of vigorous-intensity } \\
\text { leisure time PA }(>2,000 \mathrm{kcal} / \mathrm{wk}) \text { and } \\
\text { total leisure time PA ( }>3,000 \mathrm{kcal} / \mathrm{wk}) \\
\text { were protection factor for obesity }\end{array}$ \\
\hline $\begin{array}{l}\text { Lakerveld et al. } \\
{\left[60^{\bullet}\right]}\end{array}$ & Sedentary lifestyle & $\begin{array}{l}\text { Australian Diabetes, Obesity and } \\
\text { Lifestyle Study (AusDiab); } n=2,191 \\
\text { men and 2,650 women }(\geq 25 \text { years) } \\
\text { were followed up for five years. }\end{array}$ & $\begin{array}{l}\text { Men and women with abdominal obesity } \\
\text { reduced their PA levels in } 34.2 \% \text { and } \\
38.1 \% \text {, respectively. Women, but } \\
\text { not men, with higher levels of TV-viewing } \\
\text { time had higher risk for reducing } \\
\text { PA levels, independent of abdominal obesity }\end{array}$ \\
\hline $\begin{array}{l}\text { Hoehner et al. } \\
{[65 \bullet]}\end{array}$ & Build environments & $\begin{array}{l}\text { Cross-sectional analysis; } n=16,543 \\
\text { adults ( } 5017 \text { women, } 11,526 \text { men }) \\
\text { age }=18-90 \text { years }\end{array}$ & $\begin{array}{l}\text { Neighborhood walkability was associated } \\
\text { with more PA/ less driving time as well } \\
\text { as higher cardiorespiratory fitness levels } \\
\text { and lower BMI }\end{array}$ \\
\hline $\begin{array}{l}\text { Bergmann et al. } \\
\text { [80] }\end{array}$ & Alcohol consumption & $\begin{array}{l}\text { European Prospective } \\
\text { Investigation into } \\
\text { Cancer and Nutrition (EPIC) study; } \\
\text { Cross-sectional study; } n=99,381 \\
\text { men and } 158,796 \text { women }\end{array}$ & $\begin{array}{l}\text { BMI and waist circumferences values were } \\
\text { significantly increased in those men and } \\
\text { women who heavily consumed alcohol } \\
\text { ( } \geq 60 \text { and } 24 \mathrm{~g} / \text { day, respectively) }\end{array}$ \\
\hline
\end{tabular}

risk of obesity. Three studies showed no significant association between paternal age at birth and the risk of obesity [23-25]. Only one study showed a positive association, but no adjustment was made for background factors [26]. In this sense, Eriksen et al. [9] showed the relationship between paternal age at birth and the occurrence of obesity in young adulthood. For comparison, they also analyzed the relationship between maternal age at birth and the occurrence of obesity. 
The risk of obesity in young Norwegian men increases with advancing paternal age at birth but does not increase with advancing maternal age at birth. Men who were born to teenage mothers had an increased risk of obesity. The prevalence of obesity and the prevalence of overweight varied with maternal age at birth. Both the prevalence of obesity and the prevalence of overweight had a maximum at a maternal age of less than 20 years and a minimum at a maternal age of 25 29 years [9]. The increased risk of obesity and overweight among men born to teenage mothers may be due to a range of psychological and socioeconomic factors. Teenage mothers often come from a socially disadvantaged background [27]. Adolescent pregnancies are often unintended and may cause educational disruption and family conflicts. The children of teenage mothers have an increased risk of developmental delay and behavioral disorders [27]. These circumstances may have consequences for the children's eating habits and level of physical activity.

\section{Socioeconomic and Education Level}

Individual socio-cultural determinants such as parental educational level are known risk factors for childhood overweight/obesity and sedentary behaviors. The inverse association between parental education and higher adiposity in childhood may have several explanations, including relation with lower socio-economic status and its influence on knowledge and beliefs key to healthy lifestyles [28]. Although some studies $[29,30]$ found a stronger association between maternal educational level and childhood overweight, other did not identify such outcome [31]. Furthermore, in the last study, only father's educational level remained a significant multivariable analysis for boys. A reason that may explain this result is the fact that mothers usually have more responsibility and influence in feeding practices of infants and very young children [31].

According to the government's annual comprehensive report on Americans' health [7], people with higher levels of education have lower rates of obesity compared to those with less education and lower income levels. In 2007-2010, higher levels of education among the head of household resulted in lower rates of obesity among boys and girls 2 19 years of age. In households where the head of household had less than a high school education, $24 \%$ of boys and $22 \%$ of girls were obese, while those with bachelor's degree or higher as the head of household, obesity prevalence were $11 \%$ for males aged 2-19 years and $7 \%$ for females. Moreover, women 25 years of age and over with less than a bachelor's degree were more likely to be obese (39-43\% than those with a bachelor's degree or higher $(25 \%)$ between 2007 and 2010. In summary, obesity prevalence among adult males did not vary consistently with level of education, but women and children appear to be more vulnerable.

\section{Body Dissatisfaction}

Emotional well-being is a particularly important component of overall health and well-being during childhood and adolescence, in that the chronic medical conditions often affect physical health in adulthood and are comparatively uncommon earlier in life. Due to the increased prevalence of obesity in many countries in recent years, weight-related impairment in the emotional well-being of children and adolescents has come to assume greater significance in obesity research [32•].

The prevalence of obesity has increased as well as the social pressure for thinness and the associated stigmatization of obesity and thus, the discrepancy between desirable body weight and actual body weight has increased. This may easily cause distress and perceived psychosocial stress and in turn has been found to increase adiposity, especially central obesity $[8 \cdot \bullet, 33]$.

Numerous studies have documented an association between obesity and various forms of psychological distress, including anxiety and depressive disorders. However, the timing and direction of the relationship between obesity and psychological distress remain controversial. Some evidence suggests that obesity in childhood and adolescence increases the risk of developing mood or anxiety disorders in adulthood. Other studies have demonstrated that depressive symptoms, particularly if they occur early in life, increase the likelihood of obesity in adulthood, though prospective longitudinal studies are limited [13].

Mond et al. [32•] suggested that associations between obesity and impairment in emotional well-being, where these occur, are likely to be due to the effects of weightrelated body dissatisfaction. This appears to be the case for both boys and girls and during both early and late adolescence. The findings are consistent with the view that body dissatisfaction is crucial to the health and well-being of children and adolescents who are overweight and suggest that psychological distress associated with negative body image may warrant greater attention in developing programs to reduce the individual and community health burden of obesity.

Duncan et al. [34] revealed that overall, adolescent girls from a diverse range of ethnic groups tended to be poor at accurately classifying their weight status. The presence of weight misclassification across the range of body fat categories (normal weight girls perceiving themselves as overweight and girls with high body fat perceiving themselves as normal or underweight) shows the conflicting issues of body size perceptions that exist in this group. Thus, interventions 
in this subgroup of the population should focus on delivering clear, consistent messages that promote a healthy weight rather than simply weight loss.

Cuypers et al. [8・•] investigated whether self-perceived overweight in normal weight adolescents might have an impact on the development of their weight into young adulthood and showed that during the 11-year follow-up period, adolescents who perceived themselves as overweight had a mean difference in overall weight gain (delta BMI) that was $0.88 \mathrm{BMI}$ units larger than those who did not report self-perceived overweight. Additionally, adjusted for all relevant confounders, adolescents who reported selfperceived overweight had a higher gain of $0.66 \mathrm{BMI}$ units than those, who did not report self-perceived overweight. Wilkosz et al. [35] showed that adolescents whose BMI was in the 85th percentile or higher were almost three times more likely to report body dissatisfaction than were adolescents whose BMI was below the 85th percentile.

Cho et al. [36•] showed that physical and psychological well-being of pre-adolescents can be harmed by overestimating one's weight more than by being overweight. Children who overestimated their own weight had significantly greater weight dissatisfaction and interest in losing weight than those with a normal weight perception despite a similar BMI to the normal weight perception group. Moreover, the questioners answered "to look better" and "for easier movement" as reasons for dieting, which could be unhealthy and unreasonable, considering similar BMI to those in the normal perception group. Subjects who overestimated their own weights had significantly higher scores for "easily get annoyed and tired" than those without a distorted body image, suggesting an association between unjustified overestimation of their weight with at least one of the depression symptoms.

The correlation of obesity and poor body image raise a special concern because dissatisfaction with one's body has been reported to be a powerful risk factor for the development of eating disorders. Body mass is known to be the biologic characteristic that relates most strongly with body image. If children or adolescents have low self-esteem or body image issues, they could be at risk for engaging in unhealthy eating behaviors if they consider their BMI calculation as high [37].

Cuypers et al. $\left[8 \bullet^{\circ}\right]$ revealed that self-perceived overweight during adolescence may affect development of weight from adolescence into young adulthood. This highlights the importance of focusing also on body image in public health interventions against obesity, favoring a "healthy" body weight, taking into account natural differences in body shapes.

\section{Sleep Conditions and Circadian Rhythm}

Sleep is a fundamental and natural process and yet the exact purpose of sleep and its effects on health and disease remain to be fully elucidated [38]. Sleep deprivation is a common phenomenon in today's society. Over the last 50 years, daily sleep duration in adolescents and adults decreased by $1.5-2$ hours, and more than $30 \%$ of Americans between the age of 30 to 64 years old report less than 6 hours of sleep per night $[39,40 \bullet]$.

Epidemiologic and observational studies indicate that a decrease in nocturnal sleep duration is associated with higher risk of developing metabolic syndrome, diabetes and obesity $[6 \bullet \bullet, 38,41 \bullet \cdot, 42-46]$ by reducing the energy expenditure and increasing the appetite and the food intake $[41 \bullet \bullet, 47]$. Furthermore, short sleep duration and disordered sleep have been linked to numerous adverse metabolic changes, such as dysregulation of multiple hormone axes, reduced insulin sensitivity, insulin resistance, glucose intolerance, reduced leptin and augmented

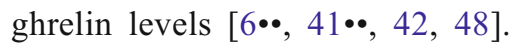

Benedict et al. [41 ••] showed that one night of sleep loss induced a decrease in energy expenditure under resting and postprandial conditions during the subsequent daytime period. A drop in energy expenditure because of sleep loss may constitute a mechanism that, in conjunction with decreased physical activity and an increased food intake after sleep deprivation, may foster the association between chronic sleep curtailment and obesity.

Park [49] observed that there was an inverse linear relationship between BMI and sleep duration in South Korean adolescents. The average BMI was highest among those who slept less than 5 hours per night, and lowest among those who slept 8 hours or more per night. The results indicated an inverse relationship between sleep duration and being overweight or obese.

St-Onge et al. [6••] assessed energy balance during periods of short $(4 \mathrm{~h} /$ night $)$ and habitual $(9 \mathrm{~h} /$ night $)$ sleep in normal-weight men and women and found that the participants consumed more energy on day 5 during short sleep $(2813.6 \pm 593.0 \mathrm{kcal})$ than during habitual sleep $(2517.7 \pm$ $593.0 \mathrm{kcal} ; P=0.023$ ). This effect was mostly due to increased consumption of fat $(20.7 \pm 37.4 \mathrm{~g} ; P=0.01)$, notably saturated fat $(8.7 \pm 20.4 \mathrm{~g} ; P=0.038)$, during short sleep. Resting metabolic rate (short sleep: $1455.4 \pm 129.0 \mathrm{kcal} / \mathrm{d}$; habitual sleep: $1486.5 \pm 129.5 \mathrm{kcal} / \mathrm{d} ; P=0.136)$ and total energy expenditure (short sleep: $2589.2 \pm 526.5 \mathrm{kcal} / \mathrm{d}$; habitual sleep: $2611.1 \pm 529.0 \mathrm{kcal} / \mathrm{d} ; P=0.832)$ did not differ significantly between sleep phases. These data show that a reduction in sleep increases energy and fat intakes, which may explain the associations observed between sleep and obesity.

Toor et al. [40•] showed that sleep duration among bariatric surgical patients is considerably less than that of individuals who are non-obese. Bariatric surgical patients prior to surgery obtained an average of $6 \mathrm{~h}$ of sleep per day. Such sleep durations are more than an hour less than those of their non- 
obese counterparts who slept for an average of $7.2 \mathrm{~h}$. Sleep durations of the bariatric surgical patients, of the non-obese controls, or of the combined groups were significantly and inversely associated with body size, such that individuals with the least amount of sleep were most likely to be overweight or obese.

Endogenous circadian rhythms are controlled by the central circadian pacemaker in the suprachiasmatic nucleus of the hypothalamus, and these rhythms help to synchronize molecular circadian clocks in peripheral cells and tissues. Peripheral clocks optimize physiological functions to match daily patterns of behavior, such as feeding, activity, and sleep. Suboptimal alignments between endogenous circadian rhythms and daily behaviors occur in many millions of people who perform shift work, and this circadian disruption may contribute to the known adverse health consequences of shift work, including fatigue and poor sleep, gastrointestinal complaints, detrimental metabolic changes, and increased risks of developing obesity and diabetes [42].

In humans, acute (a few days) misalignment of the normal circadian phases at which sleep and meals occur causes higher postprandial blood glucose, despite higher insulin concentrations in the blood. The magnitude of hyperglycemia was comparable to a prediabetic state in a third of these individuals [50].

Chronic shift work is correlated to increased BMI and risk of developing metabolic syndrome. It further affects the secretion of endocrine factors such as melatonin, growth hormone, prolactin, leptin and glucocorticoids, all of which impinge on metabolic homeostasis. It has been proposed that chronic sleep disruption may be the cause in the incidence of metabolic dysregulation and obesity in shift workers [51].

Both sleep patterns and circadian rhythms change profoundly with age. Older people experience less sleep, more frequent awakenings, a reduction of slow wave sleep, and blunting of the amplitudes of circadian rhythms such as core body temperature and activity. Also, the phase relationships between those rhythms and the timing of sleep change with age. Given the possible adverse metabolic changes caused by short sleep and circadian disruption, it is also plausible that the sleep and circadian changes with age could contribute to the increased incidence of obesity and diabetes in the elderly [42].

Mechanisms responsible for the link between sleep loss and obesity are unclear. Investigators found that shortened sleep duration is associated with a number of hormonal changes that favors fat accumulation, including an increase in ghrelin, a reduction in leptin and in the ratio of leptin to ghrelin, an increase in evening cortisol, reduced insulin sensitivity, a decrease in growth hormone, and among certain ethnicities, a decline in adiponectin. Altogether, such changes increase appetite, reduce energy expenditure, and alter fat metabolism in a manner that increases adiposity. In these ways, sleep loss contributes to weight gain and obesity. Obesity, in turn, causes physical, emotional, and environmental conditions that interfere with sleep quality and duration, setting in motion a vicious cycle whereby sleep loss "begets" obesity and obesity "begets" sleep loss [40•].

\section{Sedentary Lifestyle}

Physical activity (PA) is a recognized prevention factor for chronic adiposity accumulation. Currently, researchers has proposed a gene-interaction mechanism of PA practice, since those considered physically active have presented attenuated effect of the polymorphisms related-obesity, in particular, the fat and obesity associated (FTO) gene in children and adults $[3 \cdot \bullet, 52,53]$.

However, the balance between PA practice and sedentary behavior is as complex as the obesity etiology. In this sense, the fast changes in environmental and behavioral traits over the last decades have contributed to energy expenditure reduction. Technological advances, built environment, inactive transports and occupations, and social network have impacted the way we live at home, work and children education, leading to reduction in level and duration of PA in daily life as well as an increase in sedentary activities.

In fact, intensity, duration, and total leisure time of PA have synergy and independently reduced the risk for overweight/obesity in women and men [54-56]. In contrast, sedentary behavior, with mostly sitting occupation or screen-time (watching TV, using computer, and playing electronic games), has increased this risk in children and adults $[4 \cdot \bullet, 21,57,58]$, regardless of physical activity. In children, sedentary lifestyle was positively associated with fat infiltration within skeletal muscle during growth, which could contribute to obesity-related metabolic disorders [59]. In addition, TV-watching more than two hours per day was associated with decreased fitness, lowered scores for selfesteem and pro-social behavior, and decreased academic achievement, besides increased risk for obesity [4••]. Thus, sedentary time should be highlighted as an independent risk factor in order to prevent obesity.

Moreover, Lakerveld et al. [60•] found a reduction in physical activity of 34 and $38.1 \%$ in men and women, respectively, with abdominal obesity ( $\geq 102 \mathrm{~cm}$ and $\geq 88 \mathrm{~cm}$, respectively) compared to those with a normal waist circumference. In fact, overweight/obesity have been shown to be associated with decreased probability of meeting the recommended physical activity levels, by having more barriers to physical activity and spending more time in sedentary behaviors [57, 61].

Interestingly, women but not men, with higher levels of TV-viewing time $(\geq 4 \mathrm{~h} / \mathrm{d}$ ) had a higher decrease in physical activity levels during 5-year follow-up, independent of abdominal obesity $\left[60^{\bullet}\right]$. In a previous study, women had also 
reported more time spent in TV-viewing and other leisure-time sedentary behaviors than men [62]. These findings indicate that more exposure to sedentary behaviors and low leisure-time PA among women increases their risk for continuous and worsening obesity and morbidities-related.

\section{Build Environments}

Unfavorably built environments including low walk ability, insecurity, small number of green parks, playgrounds and pedestrian pathways, and easy access to high-calorie density beverages/food can stimulate sedentary behavior and low physical activity as well as high energy intake, with subsequently development of obesity in specific city or countries' regions.

In this sense, the increase in the walking pathways in neighborhoods has been associated with higher active transport [63, 64], lower incidence for overweight/obesity [65•, 66], and an improvement in cardiorespiratory fitness in adults and elderly people [65 ${ }^{\circ}$. In fact, the Institute of Medicine has identified improvements to the built environment that can encourage walking and bicycling, such as a well-connected network of off-street trails and paths and paths connecting destinations for such activity, as a priority [67]. For example, the building of a 6-block walking path plus school playground installation also resulted in reported increased physical activity in a low-income neighborhood of African Americans [68].

In another study with 1,818 randomly assessed Nigerian adults living in high and low socioeconomic neighborhoods, low residential density and poorly maintained pedestrian pathways were associated with overweight in men, while high traffic making it unsafe to walk was associated with overweight in women [69]. In the Quebec Adipose and Lifestyle Investigation in Youth Cohort, social fragmentation, defined as the breakdown of social bonds between individuals and their communities, was associated with reduced walking among women [70]. These findings suggest an interaction between motivation for PA or sedentary behavior, socioeconomic neighborhoods and gender.

For children, the safety in the traffic and neighborhoods as well as playground/parks accessibility have been strategies proposed to stimulate outside PA and reduced screentime [21, 71-73]. In addition, socially cohesive neighborhoods may influence youth PA by facilitative enforcement of healthy norms, community awareness of programs and facilities, collective action to improve the local area and limiting crime and disorder [74]. Taken together, current studies show that the encouragement for PA can be little effective, if it is not associated with strategies for adequate and safe buildings for its practice.

\section{Alcohol Consumption}

In a meta-analysis, a reasonable alcoholic drink consumption $(\approx 20 \mathrm{~g} / \mathrm{d})$ decreased $20 \%$ of CVD risk, while an alcohol drinking higher than $89 \mathrm{~g} / \mathrm{d}$ increased the risk, presenting a J-shape relationship between alcohol drinking and CVDrelated mortality [75]. The moderate consumption of alcohol (5-30 $\mathrm{g}$ of alcohol/d) also has been associated with lower risk of T2D, suggesting a U-shape relationship [76]. These previous findings have justified moderate alcohol consumption as a health custom. In contrast, heavy alcoholic drinking and alcoholism have been associated with weight gain in adults [77, 78] and moderate to heavy drinking with weight gain in adolescents [79]. In addition, women drinking $>24 \mathrm{~g} / \mathrm{d}$ of alcohol had presented additionally abdominal obesity, when alcohol was from beer rather than wine source [80]. Moreover, postmenopausal women who reported a moderate consumption of wine have a reduced risk for becoming overweight/ obesity over seven years, but not those who drank beer and liquor [78]. The findings suggest that chronic and high alcohol consumption can lead to positive energy balance, with increased obesity risk, while moderate alcohol consumption from specific alcoholic beverages could prevent it. However, more studies are needed to clarify this relationship, taking into account other related-behaviors, such as dietary pattern, PA behavior, genetic predisposition, etc.

\section{Conclusion: Implication and New Perspectives}

The etiology and treatments of obesity have been thoroughly investigated. The advances in technologies helped us better understand the molecular/metabolic mechanisms involved in the obesity etiology and related disorders. However, the incidence and degree of obesity have been increasing each day in the world, and, unfortunately, the strategies of modification of lifestyle and medicaments have failed in the treatment of this epidemic non-communicable disease.

In this sense, social components are as complex and important as other risk factors for obesity, and this review incites some implications and news research:

- Obesity per se, over time, may reduce PA level and social ability, exacerbating the low energy expenditure. Obesity also appears to influence assortative mating, and subsequent intergenerational obesity condition. Even so, obesity condition time may have more implication to its prevalence that we understand, associated with molecular (e.g., epigenetics) and parental characteristics (e.g., parental age and education). More studies must correlate social and metabolic/molecular components of obesity in order to assess the effect of excessive adiposity in its own occurrence and chronicity. 
- Longitudinal studies should explore the relationship between body image and/or body dissatisfaction and future weight status in order to determine whether accuracy of weight perception may lead to weight change.

- During sleep deprivation, even small undetectable changes in components of energy expenditure in the short term can have a larger effect over the long term. To explore this area, further studies using appropriate methodology and under relevant conditions in terms of sleep length and duration are needed in order to mimicreal life condition of an average short sleeper.

- Strategies for reducing sedentary lifestyle should take into account gender and age traits and include a built environment that provides safety, a beautiful place, and structural condition to nice playing or walk ability, thus increasing outside PA and reducing screen-time.

- The results also reinforce the urgent need to include obesity prevention as a relevant topic on the public health agenda in developing countries; improve the access of all social classes in these countries to reliable information on the determinants and consequences of obesity; and design and implement consistent public actions on the physical, economic, and socio-cultural environmental that makes healthier choices concerning diet and physical activity feasible for all.

In summary, more studies concerning social, cultural, environment traits are needed in order to assess the effect of excessive adiposity in its own occurrence and chronicity. In addition, it is urgent to include obesity prevention as a relevant topic on the public health agenda in developing countries.

Acknowledgments We thank The CAPES Foundation (MEC/ Brazil) for research grant to F.C.V. and financial support.

Disclosure No potential conflicts of interest relevant to this article were reported.

\section{References}

Papers of particular interest, published recently, have been highlighted as:

- Of importance

-• Of major importance

1. WHO. Global health risk: mortality and burden of disease attributable to selected major risks. Geneva: World Health Organization; 2009.

2. Martí A, Martínez-González MA, Martínez JA. Interaction between genes and lifestyle factors on obesity. Proc Nutr Soc. 2008;67(1):1-8.

3. • Kilpeläinen TO, Qi L, Brage S, Sharp SJ, Sonestedt E, Demerath E, et al. Physical activity attenuates the influence of FTO variants on obesity risk: a meta-analysis of 218,166 adults and 19,268 children. PLoS Med. 2011;8(11):e1001116. This meta-analysis demonstrated that the association of FTO gene risk allele with obesity was attenuated by $27 \%$ in physically active adults, highlighting the importance of $P A$ in prevention obesity from analysis of 45 studies.

4. •- Tremblay MS, LeBlanc AG, Kho ME, Saunders TJ, Larouche R, Colley RC, et al. Systematic review of sedentary behaviour and health indicators in school-aged children and youth. Int J Behav Nutr Phys Act. 2011;8:98. This paper is an excellent meta-analysis that measured the dose response of sedentary behavior on health indicators, with emphasis in watching TV and spent screen-time, in children and youth aged 5-17 years. Interestingly, TV-watching $>2 \mathrm{~h} /$ day was associated with increased risk for obesity, decreased fitness, lowered scores for self-esteem and pro-social behavior, and decreased academic achievement.

5. - Pérez-Pastor EM, Metcalf BS, Hosking J, Jeffery AN, Voss LD, Wilkin TJ. Assortative weight gain in mother-daughter and fatherson pairs: an emerging source of childhood obesity. Longitudinal study of trios (EarlyBird 43). Int J Obes (Lond). 2009;33(7):727-35. This paper demonstrated that same-sex parent obesity can contribute to obesity's children.

6. •- St-Onge MP, Roberts AL, Chen J, Kelleman M, O'Keeffe M, RoyChoudhury A, et al. Short sleep duration increases energy intakes but does not change energy expenditure in normal-weight individuals. Am J Clin. 2011;94(2):410-6. A reduction in sleep increases energy and fat intakes, which may explain the associations observed between sleep and obesity.

7. NCHS. National Center for Health Statistics. Health, United States. With special feature on Socioeconomic Status and Health. Hyattsville: NCHS; 2011. p. 2011.

8. •• Cuypers K, Kvaløy K, Bratberg G, Midthjell K, Holmen J, Holmen TL. Being normal weight but feeling overweight in adolescence may affect weight development into young adulthood-an 11-year followup: The HUNT Study, Norway. J Obes. 2012;2012:8. This excellent prospective study revealed that selfperceived overweight during adolescence may affect development of weight from adolescence into young adulthood.

9. Eriksen W, Sundet JM, Tambs K. Paternal age at birth and the risk of obesity in young adulthood: a register-based birth cohort study of norwegian males. Am J Hum Biol. 2012.

10. Sikorski C, Luppa M, Kaiser M, Glaesmer H, Schomerus G, Konig $\mathrm{H}-\mathrm{H}$ et al. The stigma of obesity in the general public and its implications for public health - a systematic review. BMC Public Health.11(1):661.

11. Babio N, Canals J, Pietrobelli A, Pérez S, Arija V. A two-phase population study: relationships between overweight, body composition and risk of eating disorders. Nutr Hosp. 2009;24(4):485-91.

12. Sanchez-Villegas A, Pimenta AM, Beunza JJ, Guillen-Grima F, Toledo E, Martinez-Gonzalez MA. Childhood and young adult overweight/obesity and incidence of depression in the SUN project. Obesity (Silver Spring). 2010;18(7):1443-8.

13. Kubzansky LD, Gilthorpe MS, Goodman E. A prospective study of psychological distress and weight status in adolescents/young adults. Ann Behav Med. 2012;43:219-28.

14. Speakman JR, Djafarian K, Stewart J, Jackson DM. Assortative mating for obesity. Am J Clin Nutr. 2007;86(2):316-23.

15. Jääskeläinen A, Pussinen J, Nuutinen $O$, Schwab U, Pirkola J, Kolehmainen $\mathrm{M}$, et al. Intergenerational transmission of overweight among Finnish adolescents and their partents: a 16year follow-up study. Int J Obes (Lond). 2011;35(10):128994.

16. Ajslev TA, Angquist L, Silventoinen K, Gamborg M, Allison DB, Baker JL, et al. Assortative marriages by body mass index have increased simultaneously with the obesity epidemic. Front Genet. 2012;3:125 
17. Kye B, Mare RD. Intergenerational effects of shifts in women's educational distribution in South Korea: transmission, differential fertility, and assortative mating. Soc Sci Res. 2012;41(6):1495514.

18. Ajala O, Hosking J, Metcalf BS, Jeffery AN, Voss LD, Wilkin TJ. The contribution of parental BMI to the metabolic health of their offspring: a longitudinal cohort study (EarlyBird 55). Pediatr Obes. 2012;7(2):143-50.

19. Allison DB, Neale MC, Kezis MI, Alfonso VC, Heshka S, Heymsfield SB. Assortative mating for relative weight: genetic implications. Behav Genet. 1996;26(2):103-11.

20. Pawlowski B. Variable preferences for sexual dimorphism in height as a strategy for increasing the pool of potential partners in humans. Proc Biol Sci. 2003;270(1516):709-12.

21. Veitch J, van Stralen MM, Chinapaw MJ, te Velde SJ, Crawford D, Salmon J, et al. The neighborhood social environment and body mass index among youth: a mediation analysis. Int J Behav Nutr Phys Act. 2012;9:31.

22. Toriello HV, Meck JM. Statement on guidance for genetic counseling in advanced paternal age. Genet Med. 2008;10(6):457-60.

23. Celi F, Bini V, De Giorgi G, Molinari D, Faraoni F, Di Stefano G, et al. Epidemiology of overweight and obesity among school children and adolescents in three provinces of central Italy, 1993-2001: study of potential influencing variables. Eur J Clin Nutr. 2003;57(9):1045-51.

24. Agras WS, Hammer LD, McNicholas F, Kraemer HC. Risk factors for childhood overweight: a prospective study from birth to 9.5 years. J Pediatr. 2004;145(1):20-5.

25. Huus K, Ludvigsson JF, Enskar K, Ludvigsson J. Risk factors in childhood obesity-findings from the All Babies In Southeast Sweden (ABIS) cohort. Acta Paediatr. 2007;96(9):1321-5.

26. Wilkinson PW, Parkin JM, Pearlson J, Philips PR, Sykes P. Obesity in childhood: a community study in Newcastle upon Tyne. Lancet. 1977;1(8007):350-2.

27. Klein JD. Adolescent pregnancy: current trends and issues. Pediatrics. 2005;116(1):281-6.

28. Shrewsbury V, Wardle J. Socioeconomic status and adiposity in childhood: a systematic review of cross-sectional studies 1990 2005. Obesity (Silver Spring). 2008;16(2):275-84.

29. Moreno LA, Tomas C, Gonzalez-Gross M, Bueno G, Perez-Gonzalez JM, Bueno M. Micro-environmental and socio-demographic determinants of childhood obesity. Int J Obes Relat Metab Disord. 2004;28 Suppl 3:S16-20.

30. Serra-Majem L, Aranceta Bartrina J, Perez-Rodrigo C, RibasBarba L, Delgado-Rubio A. Prevalence and deteminants of obesity in Spanish children and young people. Br J Nutr. 2006;96 Suppl 1: S67-72.

31. Santiago S, Zazpe I, Cuervo M, Martinez JA. Perinatal and parental determinants of childhood overweight in 6-12 years old children. Nutr Hosp. 2012;27(2):599-605.

32. - Mond J, van den Berg P, Boutelle K, Hannan P, NeumarkSztainer D. Obesity, body dissatisfaction and emotional wellbeing in early and late adolescence: findings from the Project EAT study. J Adolesc Health. 2011;48(4):373-8. This paper revealed that impairment in the emotional well-being of overweight adolescents, where this is observed, may be due primarily to the effects of weight-related body dissatisfaction.

33. Matthiasdottir E, Jonsson SH, Kristjansson AL. Body weight dissatisfaction in the Icelandic adult population: a normative discontent? Eur J Publ Health. 2012;22(1):116-21.

34. Duncan JS, Duncan EK, Schofield G. Associations between weight perceptions, weight control and body fatness in a multiethnic sample of adolescent girls. Public Health Nutr. 2011;14:93-100.

35. Wilkosz ME, Chen J-L, Kenndey C, Rankin S. Body dissatisfaction in California adolescents. J Am Acad Nurse Pract. 2011;23 (2):101-9.
36. - Cho JH, Han SN, Kim JH, Lee HM. Body image distortion in fifth and sixth grade students may lead to stress, depression, and undesirable dieting behavior. Nutr Res Pract. 2012;6(2):175-81. This paper emphasizes the importance of having an undistorted body image.

37. Portilla MG. Body mass index reporting through the school system: Potential harm. J Am Diet Assoc. 2011;111(3):442-5.

38. Miller MA. Association of inflammatory markers with cardiovascular risk and sleepiness. J Clin Sleep Med. 2011;7(5):S31-3.

39. Alves ES, Lira FS, Santos RV, Tufik S, de Mello MT. Obesity, diabetes and OSAS induce of sleep disorders: exercise as therapy. Lipids Health Dis. 2011;10:148.

40. - Toor P, Kim K, Buffington CK. Sleep quality and duration before and after bariatric surgery. Obes Surg. 2012;22:890-5. This study showed that individuals with extreme obesity, compared to the nonobese, obtain less sleep and experience poorer sleep quality. Furthermore, bariatric surgery improves sleep duration and quality.

41. •• Benedict C, Hallschmid M, Lassen A, Mahnke C, Schultes B, Schiöth HB, et al. Acute sleep deprivation reduces energy expenditure in healthy men. Am J Clin Nutr. 2011;93:1229-36. According to this randomized and balanced crossover study, one night of sleep deprivation acutely may reduce energy expenditure in healthy men.

42. Buxton OM, Cain SW, O'Connor SP, Porter JH, Duffy JF, Wang $\mathrm{W}$, et al. Adverse metabolic consequences in humans of prolonged sleep restriction combined with circadian disruption. Sci Transl Med. 2012;4(129):129ra43.

43. Klingenberg L, Chaput JP, Holmbäck U, Jennum P, Astrup A, Sjödin A. Sleep restriction is not associated with a positive energy balance in adolescent boys. Am J Clin Nutr. 2012;96(2):240-8.

44. Klingenberg L, Sjödin A, Holmbäck U, Astrup A, Chaput JP. Short sleep duration and its association with energy metabolism. Obes Rev. 2012;13(7):565-77.

45. Knutson KL. Sociodemographic and cultural determinants of sleep deficiency: Implications for cardiometabolic disease risk. Soc Sci Med. 2012.

46. Knutson KL. Does inadequate sleep play a role in vulnerability to obesity? Am J Hum Biol. 2012;24(3):361-71.

47. Gonnissen HKJ, Hursel R, Rutters F, Martens EAP, Westerterp Plantenga MS. Effects of sleep fragmentation on appetite and related hormone concentrations over $24 \mathrm{~h}$ in healthy men. Br J Nutr; 2012:1-9.

48. Martins PJ, Fernandes L, Oliveira AC, Tufik S, D'Almeida V. Type of diet modulates the metabolic response to sleep deprivation in rats. Nutr Metabol. 2011;8(1):86.

49. Park S. Association between short sleep duration and obesity among South korean adolescents. West J Nurs Res. 2011;33(3):207-23.

50. Scheer FA, Hilton MF, Mantzoros CS, Shea SA. Adverse metabolic and cardiovascular consequences of circadian misalignment. Proc Natl Acad Sci USA. 2009;106(11):4453-8.

51. Barclay JL, Husse J, Bode B, Naujokat N, Meyer-Kovac J, Schmid $\mathrm{SM}$, et al. Circadian desynchrony promotes metabolic disruption in a mouse model of shiftwork. PLoS One. 2012;7(5):e37150.

52. Kaakinen M, Laara E, Pouta A, Hartikainen AL, Laitinen J, Tammelin $\mathrm{TH}$, et al. Life-course analysis of a fat mass and obesity-associated (FTO) gene variant and body mass index in the Northern Finland Birth Cohort 1966 using structural equation modeling. Am J Epidemiol. 2010;172(6):653-65.

53. Xi B, Wang C, Wu L, Zhang M, Shen Y, Zhao X, et al. Influence of physical inactivity on associations between single nucleotide polymorphisms and genetic predisposition to childhood obesity. Am J Epidemiol. 2011;173(11):1256-62.

54. Britton KA, Lee IM, Wang L, Gaziano JM, Manson JE, Buring JE, et al. Physical activity and the risk of becoming overweight or obese in middle-aged and older women. Obesity (Silver Spring). 2012;20(5):1096-103. 
55. Scheers T, Philippaerts R, Lefevre J. Patterns of physical activity and sedentary behavior in normal-weight, overweight and obese adults, as measured with a portable armband device and an electronic diary. Clin Nutr. 2012;31(5):756-64.

56. Spees CK, Scott JM, Taylor CA. Differences in amounts and types of physical activity by obesity status in US adults. Am J Health Behav. 2012;36(1):56-65.

57. Thorp AA, Healy GN, Owen N, Salmon J, Ball K, Shaw JE, et al. Deleterious associations of sitting time and television viewing time with cardio-metabolic risk biomarkers: AusDiab 2004-2005. Diabetes Care. 2010;33(2):327-34.

58. Chau JY, van der Ploeg HP, Merom D, Chey T, Bauman AE. Cross-sectional associations between occupational and leisuretime sitting, physical activity and obesity in working adults. Prev Med. 2012;54(3-4):195-200.

59. Farr JN, Van Loan MD, Lohman TG, Going SB. Lower physical activity is associated with skeletal muscle fat content in girls. Med Sci Sports Exerc. 2012;44(7):1375-81.

60. • Lakerveld J, Dunstan D, Bot S, Salmon J, Dekker J, Nijpels G, et al. Abdominal obesity, TV-viewing time and prospective declines in physical activity. Prev Med. 2011;53(4-5):299-302. This paper described a longitudinal study that demonstrated the contribution of obesity and sedentary time to reduction in physical activity 5year follow-up.

61. Atlantis E, Barnes EH, Ball K. Weight status and perception barriers to healthy physical activity and diet behavior. Int J Obes (Lond). 2008;32(2):343-52.

62. Sugiyama T, Healy GN, Dunstan DW, Salmon J, Owen N. Is television viewing time a marker of a broader pattern of sedentary behavior? Ann Behav Med. 2008;35(2):245-50.

63. Saelens BE, Handy SL. Built environment correlates of walking: a review. Med Sci Sports Exerc. 2008;40(7 Suppl):S550-66.

64. King AC, Sallis JF, Frank LD, Saelens BE, Cain K, Conway TL, et al. Aging in neighborhoods differing in walkability and income: associations with physical activity and obesity in older adults. Soc Sci Med. 2011;73(10):1525-33.

65. - Hoehner CM, Handy SL, Yan Y, Blair SN, Berrigan D. Association between neighborhood walkability, cardiorespiratory fitness and body-mass index. Soc Sci Med. 2011;73(12):1707-16. This paper demonstrated the relationship between neighborhood walkability and cardiorespiratory fitness among young adults and between neighborhood walkability and BMI among older adults in a cross-sectional study (16,543 participants), indicating the relevance of built environment traits on physical activity practice.

66. Auchincloss AH, Mujahid MS, Shen M, Michos ED, Whitt-Glover MC, Diez Roux AV. Neighborhood health-promoting resources and obesity risk (the Multi-Ethnic Study of Atherosclerosis). Obesity (Silver Spring). 2012. doi:10.1038/oby.2012.91.

67. IOM. Institute of Medicine. Report brief: local government actions to prevent childhood obesity. Washington: Institute of Medicine; 2009.
68. Gustat J, Rice J, Parker KM, Becker AB, Farley TA. Effect of changes to the neighborhood built environment on physical activity in a low-income African American neighborhood. Prev Chronic Dis. 2012;9:E57.

69. Oyeyemi AL, Adegoke BO, Oyeyemi AY, Deforche B, De Bourdeaudhuij I, Sallis JF. Environmental factors associated with overweight among adults in Nigeria. Int $\mathrm{J}$ Behav Nutr Phys Act. 2012;9:32.

70. Pabayo R, Barnett TA, Datta GD, Lambert M, O'Loughlin J, Kawachi I. Area-level social fragmentation and walking for exercise: cross-sectional findings from the Quebec Adipose and Lifestyle Investigation in Youth Study. Am J Public Health. 2012;102 (9):e30-7.

71. Caroli M, Malecka-Tendera E, Epifani S, Rollo R, Sansolios S, Matusik $\mathrm{P}$, et al. Physical activity and play in kindergarten age children. Int J Pediatr Obes. 2011;6 Suppl 2:47-53.

72. Colella D, Morano M. Gross motor development and physical activity in kindergarten age children. Int J Pediatr Obes. 2011;6 Suppl 2:33-6.

73. Wall MM, Larson NI, Forsyth A, Van Riper DC, Graham DJ, Story MT, et al. Patterns of obesogenic neighborhood features and adolescent weight: a comparison of statistical approaches. Am J Prev Med. 2012;42(5):e65-75.

74. Cradock AL, Kawachi I, Colditz GA, Gortmaker SL, Buka SL. Neighborhood social cohesion and youth participation in physical activity in Chicago. Soc Sci Med. 2009;68(3):427-35.

75. Corrao G, Rubbiati L, Bagnardi V, Zambon A, Poikolainen K. Alcohol and coronary heart disease: a meta-analysis. Addiction. 2000;95(10):1505-23.

76. Carlsson S, Hammar N, Grill V. Alcohol consumption and type 2 diabetes Meta-analysis of epidemiological studies indicates a U-shaped relationship. Diabetologia. 2005;48 (6): 1051-4.

77. Sanvisens A, Rivas I, Bolao F, Tor J, Roson B, Rey-Joly C, et al. Gender and liver, nutritional and metabolic alterations of severe alcoholism: a study of 480 patients. Med Clin (Barc). 2011;137 (2):49-54.

78. Thomson CA, Wertheim BC, Hingle M, Wang L, Neuhouser ML, Gong $\mathrm{Z}$, et al. Alcohol consumption and body weight change in postmenopausal women: results from the Women's Health Initiative. Int J Obes (Lond). 2012;36(9):1158-64.

79. Croezen S, Visscher TL, Ter Bogt NC, Veling ML, HavemanNies A. Skipping breakfast, alcohol consumption and physical inactivity as risk factors for overweight and obesity in adolescents: results of the E-MOVO project. Eur J Clin Nutr. 2009;63(3):405-12.

80. Bergmann MM, Schutze M, Steffen A, Boeing H, Halkjaer J, Tjonneland A, et al. The association of lifetime alcohol use with measures of abdominal and general adiposity in a large-scale European cohort. Eur J Clin Nutr. 2011;65(10):1079-87. 